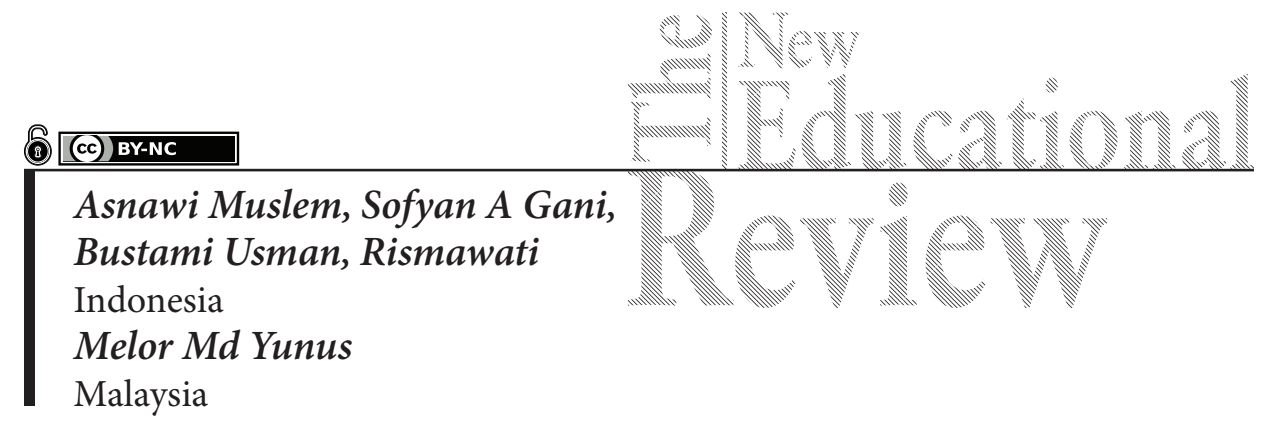

\title{
The Influence of Authentic English Video Clips on Students' Listening Comprehension
}

DOI: 10.15804/tner.2018.53.3.09

\begin{abstract}
Various methods of teaching English to EFL students in Indonesia have been used to increase their language skills. However, students' English proficiency is still not satisfactory. Therefore, this paper aimed at investigating the effects of using authentic English video clips to improve listening comprehension among EFL students in Aceh, Indonesia. A quasi-experimental group design with non-randomized pretest-posttest control was employed in this study. The sample of the study were 68 second-year students of State Senior High School 4 Banda Aceh. The experimental group was treated by using authentic English video clips and the control group was taught by using audio compact disc (CD). A listening test was used as an instrument to collect data. Analysis of variance (ANOVA) was used to analyze the data collected. Results showed that the use of authentic English video clips significantly improved students' achievement in listening comprehension in comparison to those taught by using audio compact disc (CD), i.e., there was a significant difference between students who were taught by using authentic English video clips and students who were taught by using audio compact disc (CD) in terms of listening comprehension.
\end{abstract}

Keywords: authentic video clips, audio compact disc, EFL student, listening comprehension 


\section{Introduction}

Teachers of English have employed many methods of improving EFL students' English language skills (Vijayavalsalan, 2016; Malinina, 2016). However, students' ability to use and understand English is not satisfactory (Muslem \& Abbas, 2017). Knowing the problem, the authors proposed an alternative approach to improve students' English language skills, particularly listening, through implementing authentic English video clips taken from YouTube. This approach is actually not new for students and teachers for whom English is a second language, in Malaysia, Singapore, Hong Kong, Nigeria, Africa, the Philippines, etc. However, for teachers and students for whom English is a foreign language, like those in Indonesia, Thailand, Japan, China, Turkey, etc., using authentic English video clips can be one of the best alternative approaches to enhance their English skills. Therefore, this study is aimed at investigating the effect of authentic English video clips on students' listening comprehension among EFL students in Aceh, Indonesia. The presence of technology in the field of education is helpful for many educators in general and for teachers and students who are learning English in particular (Hubbard, 2007; Yang, Chen, \& Chang Jeng, 2010; Malinina, 2016; Lee, \& Kim, 2016). Using English video clips with English subtitled text helps students to learn and acquire the language effectively for two reasons. First, students' comprehension could be improved by seeing the language in use because meanings and moods are often conveyed through visual clues. Second, video clips offer students opportunities to look at situations far beyond their classroom activities to enable them to raise their cultural awareness (Celce-Murcia, 1991; Saeedi \& Biri, 2016). Thus, the best alternative is learning English through technology (authentic video clips), as it is not expensive and could be enjoyable and could have a greater impact on the quality of their English proficiency. Authentic English video clips, e.g., offers instructors a wide variety of resource materials to be employed in EFL classrooms to improve students' listening comprehension (Schmidt-Rinehart, 1994; Peacock, 1997; Abdal, 2012; Woottipong, 2014). Therefore, using authentic video clips from YouTube can be one of the best solutions. A successful English as Second Language (ESL) interaction between school teachers and students depends primarily on effective interactive listening skills (Rogers and Medlley, 1988; Nunan, 1999; Brown, 2006; Chung, 2002; Thomson, 2004; Woottipong, 2014; Yunus, Salehi, and Amini, 2016). Kilickaya (2004) adds that authentic materials allows for exposure to real language because it is used in its own community. Furthermore, authentic video clips can be used in the classroom to promote listening comprehension since the speakers in the clips are native speakers (Krashen, 1982; Clarke, 1989; Stempleski and Tomalin, 1990; Bacon \& Finnemann, 
1990; Herron and Seay, 1991; Bacon, 1992; Ur, 1996; Hadley, 2001; Martinez, 2002; Nunan, 2003; Miller, 2005; Shian and Yunus, 2017; Lappo, 2017).

It is important to determine what media to use in teaching students (Juszczyk, Karasová, Kostelanský, Chanasová, hrinová, Vargová, 2017). The implementation of authentic video clips may attract students' attention, concentration, generate ideas, create a sense of anticipation, energize, and draw on imagination, increase the memory of content, increase understanding, create creativity, stimulate ideas, engage in the learning process, provide a rich opportunity, environment, free expression, create collaboration, motivate to learn, bring fun, decrease anxiety, and create memorable visual images during the learning process (King, 2002; Berk, 2009). Videos like movies, YouTube, TV programs, and music can also be used to improve students' listening comprehension in the classroom (Berk, 2009). Many previous studies reported that the use of authentic videos improve students' listening comprehension (Sherman, 2003; Wilberschied and Berman, 2004; Shrosbree, 2008; Shabunt, 2011; Benet, 2012; Martinez, 2013; Hsu, Hwang, Chang, and Chang, 2013). Based on the abovementioned, this study is trying to answer the following research question: "Is there any significant difference between the listening comprehension achievement of students who are taught by using English video clips and students who are taught by using audio compact discs (CD)?"

\section{Research Problem}

The English language is taught and learned in Indonesia starting from junior high school up to the university level; three years at junior high school, three years at senior high school, one year at university. Thus, a student learns English for seven years. However, students' competence in using and understanding English in communication is still low. It should not be so, but this is Indonesian students' problem even though English teachers, experts, instructors, government, and other respective parties have tried to resolve the problem. Therefore, the authors proposed an innovative approach to improve students' English language skills, particularly the listening skill, through authentic English video clips downloaded from YouTube. This way of learning English is common among students for whom English is a second language, but for students for whom English language is not a second language, it becomes a new thing to be used to improve language skills, especially the listening skill.

\section{Research Focus}

The study focuses on the implementation of authentic English video clips to enhance the listening comprehension achievement of the second-grade students 
of Senior High School in Banda Aceh, Indonesia. The main area of improving students' listening comprehension is listening for the main ideas, listening for general understanding (gist), listening for specific information, and listening for detail. At the end of the treatment, it can be seen which sub-aspects of listening have improved significantly.

\section{Research Methodology}

\section{Research General Background}

Although English is taught in Indonesia starting from junior high school up to the university level, the ability to use English for communication is still inadequate. This fact encouraged the authors to do experimental teaching on the implementation of authentic English video clips to enhance students' listening comprehension. This study aimed at finding the answer to the question mentioned above. Therefore, a quasi-experiment with non-randomized pretest-posttest control group design was employed in this study. This experimental design involved two groups of students (experimental and control groups). The experimental group was treated with authentic English video clips and the other group was taught with the use of authentic English audio materials. All teaching materials included in the file were the same but in different form, i.e., video and audio. The teaching materials used in the study were downloaded from YouTube. The two classes were given the same materials but the control group in the form of compact discs. To check the reliability and validity of the teaching materials used in the study, the authors sent the materials to two senior English teachers at the school. They confirmed that the teaching materials used in the study were suitable and appropriate for the students' level.

\section{Research Sample}

The total sample of the study included 68 students. They were divided into two groups, 38 students in the experimental groups and 38 in the control group. The experimental group was taught with the use of authentic English video clips and the control one was taught with the use of English compact discs.

\section{Instrument and Procedures}

The instrument used in this study was a set of listening tests that was taken from the final national examinations in 2009, 2010, 2012 and 2013. From the four sets of the test, the authors selected 30 items at random. The instrument of this study was 
reliable and valid because the tests were selected from the tests used in the final examination provided by the government. After administering the pretest to both group, the treatment of both groups started. The treatment lasted two months. The experimental group was taught with the use of authentic English video clip materials, whereas the control group was taught by using English compact discs. Both groups received the same materials but in different form, video and audio. After the treatment, a posttest was given to both groups, which consisted of 30 items, like in pretest.

\section{Data Analysis}

The data collected from the pretest and posttest were analyzed by using ANOVA to find differences between the experimental and control groups in terms of the students' achievement in listening comprehension. The normality and homogeneity of the tests were checked. The results of tests were normal, as reported below. The result of normality test of the pretest of both the experimental and control groups showed that the significance value is 0.533 ( $\mathrm{p}>0.05)$ for the experimental group, and the significance value is 0.243 ( $\mathrm{p}>0.05$ ) for the control group. Thus, the distribution of the pretest data for both the experimental and control groups was normal. The following also reported the normality of test on the posttest of both groups. It reported the result of normality test on the posttest of both the experimental and control groups. It showed that the significant value is 0.825 ( $\mathrm{p}>0.05)$ for the experimental group, and the significant value for the control group is 0.232 ( $p>0.05)$. Thus, the distribution of the posttest data for both the experimental and control groups was normal.

\section{Research Results}

The objective of the study is to investigate the use of authentic English video clips to enhance EFL students' listening comprehension. The results of t-test on the pretest of both the experimental and control groups showed that tobtain of both pretests of the experimental and control groups was 0.489 . The $t_{\text {table }}$ for $\mathrm{df}=66$ at the level of significance $5 \%(\alpha=0.5)$ is 2.00 . The outcome points out that tobtain $<t_{\text {table }}$ is $0.489<2.00$. Therefore, H0 was accepted. It indicated that there was no significant difference in listening achievement between the students in the experimental and control groups before the treatment. The results of $\mathrm{t}$-test on the posttest of both experimental and control groups showed that $t_{\text {obtain }}$ of both posttest of experimental and control groups was 3.766. The $t_{\text {table }}$ for $\mathrm{df}=66$ at the 
level of significance $5 \%(\alpha=0.5)$ was 2.00 . It showed that $t_{\text {obtain }}>t_{\text {table }}$ was $3.766>$ 2.00. Therefore, $\mathrm{H} 0$ was rejected. There was a significant difference in listening achievement between the students in the experimental and control groups. It can be concluded that the use of authentic English video clips is effective to improve students' listening comprehension.

The result of t-test on the pretest and posttest of the experimental group showed that the $\mathrm{t}$-test of the experimental group is 11.512 . The $t_{\text {table }}$ for $\mathrm{df}=34$ at the level of significance $5 \%(\alpha=0.5)$ is 2.04 . The result of t-test on the pretest and posttest of the control group showed that the t-test of control group is 4.064 . The $t_{\text {table }}$ for $\mathrm{df}=29$ at the level of significance $5 \%(\alpha=0.5)$ is 2.04 . The result confirms that $t_{\text {obtain }}>t_{\text {table }}$ for both of the groups is $11.512>2.04$ for the experimental group and $4.064>2.04$ for the control group. It reveals that both of the groups show better performance in listening achievement after the treatment. Nevertheless, the result of t-test in the experimental group is larger than the t-test in the control group $(11.512>4.064)$. It shows that there is a remarkable enhancement in the experimental group compared to the control group. The group taught using authentic videos shows a significant increase in score as compared to the control group, which was taught using the audio compact discs (CD) as a usual listening aid used by the teacher in teaching listening.

\section{Discussion}

Analysis of the findings showed that the use of authentic video clips improved the students' achievement in listening comprehension. Wootttipong (2014), who reported that students' English listening ability increased significantly after learning with videos, supports the study findings. The findings are in line with the finding reported by Shian and Yunus (2017). The listening achievement improved for the following reasons. First, the teaching materials were presented in the form of audio visuals, so that students could not only listen to the voice of native speakers, but also see clearly the action of the native speakers when speaking. Second, analysis of the findings from the questionnaire on motivation in learning was high (Chung, 2002; Mirvan, 2013, as cited in Woottipong, 2014). Using authentic English videos in the learning process helped and encouraged the students to study English sincerely (River, 1981; Kohonen, 1992; Canning-Wilson, 2000; Çakir, 2006; Woottipong, 2014; Sherman, 2003; Wagner, 2010). This finding was in line with the previous studies in which the use of authentic video improved students' listening skill (Hadley, 2001; Nunan, 2003; Gilmore, 2007; Shabunt, 
2011; Benet, 2012; Martinez, 2013; Muslem et al., 2017). Using authentic videos in teaching listening can develop learner autonomy by providing students with numerous opportunities to practice their listening skill (Wagner, 2010; Shian and Yunus, 2017). Furthermore, the visual appearance of native speakers and their surroundings may assist learners when listening to their conversations, particularly in building up the communication context (Woottipong, 2014). Students can observe clearly the context or the situation of conversations. It undeniably helps the students listening to the content of the utterances or speech without having to guess the context of the conversations.

\section{Conclusions}

The use of authentic English video clips successfully improved the second-grade EFL students' listening comprehension at State Senior High School (SSHS) 4 Banda Aceh as compared to the students who were taught by using authentic English audio teaching materials. The presented study also confirmed that the use of these teaching materials enables students to familiarize with the normal rate of utterances in English. The more EFL students deal with the authentic English video teaching materials, the more they can improve and increase the quality of EFL learning and acquisition. Students also can learn the culture of the English language naturally and spontaneously so that they can use and understand the information in English automatically. Using this media of learning enables students to learn independently. This study has contributed to provide a realistic model of improving students' listening achievement among EFL students whose native language is not English. This approach of teaching is not new for students whose second language is English, like Malaysia, Singapore, the Philipines, and Negeria. In contrast, it is a new way of improving listening skill for Indonesian students whose second language is not English.

\section{References}

Abdal, H.F. (2012). Listening Comprehension Strategies of Arabic-Speaking ESL Learners. Fort Collins, Colorado: Unpublished Graduate Thesis of Colorado State University.

Bacon, S.M., \& Finneman, M.D (1990). A study of the attitudes, motives, and strategies of university foreign language students and their disposition to authentic oral and written input. The Modern Language Journal, 74(4), 459-473.

Benet, C. (2012). Teaching listening strategies with authentic videos: An intervention 
study with EFL secondary school students in Catalonia. Catalonia: Unpublished Thesis of University of Barcelona.

Berk, R.A. (2009). Multimedia teaching with video clips: TV, movies, YouTube, and mtvU in the college classroom. International Journal of Technology in Teaching and Learning, $5(1), 1-21$.

Brown, S. (2006). Teaching Listening. New York: Cambridge University Press.

Çakir, D.I. (2006). The use of video as an audio-visual material in foreign language teaching classroom. The Turkish Online Journal of Educational Technology, 5(4), 67-72.

Canning-Wilson, C. (2000). Research in Visuals. Invited Paper for the Video Special Interest Group at the International TESOL Arabia 2000 Conference, Hilton Ballroom: Hilton Hotel.

Celce-Murcia, M., \& McIntosh, L. (1991). Teaching English as a second or foreign language.

Chung, J.M. (2002). The effects of using two advance organizers with video texts for the teaching of listening in English. Foreign Language Annals, 35(2), 231-241.

Clarke, D.(1989). Communicative Theory and Its Influence on Materials Production. Language Teaching, 22, 73-86.

Gilmore, A. (2007). Authentic materials and authenticity in foreign language learning. Language teaching, 40(02), 97-118.

Hubbard, P. (2007). Technology and Listening. The encyclopedia of applied linguistics. Hadley, A. (2001). Teaching language in context (3rd ed.). Boston: Thomson Heinle.

Herron, C., \& Seay, I. (1991). The effect of authentic oral texts on student listening comprehension in the foreign language classroom. Foreign Language Annals, 24(6), 487-495.

Hsu, C.K., Hwang, G.J., Chang, Y.T., \& Chang, C.K. (2013). Effects of Video Caption Modes on English Listening Comprehension and Vocabulary Acquisition Using Handheld Devices. Educational Technology \& Society, 16(1), 403-414.

Juszczyk, S., Karasová, M., Kostelanský, A., Chanasová, Z., Uhrinová, M., \& Vargová, M. Family as One of the Key Determinants of Media Education of Young School-age Children. The New Educational Review, 4 (50), 94-108.

Kilickaya. F. (2004). Authentic materials and cultural content in EFL classrooms. The Internet TESL Journal, 10(7). Retrieved April 7, 2015 from http://iteslj.org/Techniques/ Kilickaya-AutenticMaterial.html

King, J. (2002). Using DVD feature films in the EFL classroom. Computer Assisted Language Learning, 15 (5), 509-523

Kohonen, V. (1992). Experiential language learning: second language learning as cooperative learner education. Collaborative language learning and teaching, 1439.

Krashen, S. (1982). Principles and Practice in Second Language Acquisition. New York: Pergamon Press.

Lappo, V. (2017). Technology of attraction of film art works in the spiritual values education process of high school students. The New Educational Review, 3(49), 213-223.

Lee, J., Koo, Y., \& Kim, M.H. (2016). Enhancing Problem Solving Skills in Science Edu- 
cation with Social Media and an e-Collaboration Tool. The New Educational Review, 1 (43), 248.

Malinina, I.A. (2016). implementing Web 2.0 Tools for Collaborative Work of Learners Studying English. The New Educational Review, 1 (43), 104.

Martinez, A. (2002). Authentic materials: An overview. Karen's Linguistic Issues. Retrieved February 12, 2015. From http://www3.telus .net/linguistic issues/authenticmaterials. html

Martinez, J.Y. (2013). The use of authentic videos for listening comprehension in a private school in Pereira. Pereira: Unpublished Thesis of University of Pereira.

Miller, M. (2005). Improving aural comprehension skills in EFL, using authentic materials: an experiment with university students in Nigata, Japan. Unpublished master's thesis of University of Surrey, Australia.

Muslem, A., \& Abbas, M. (2017). The effectiveness of immersive multimedia learning with peer support on

English speaking and reading aloud. International Journal of Instruction, 10(1), 203-218.

Muslem, A., Mustafa, F., Usman, B., \& Rahman (2017). The application of video clips with small group and individual activities to improve young learners' speaking performance. Teaching English with Technology, 17(4), 25-37.

Nunan, D. (1999). Second Language Teaching \& Learning. Heinle \& Heinle Publishers, 7625 Empire Dr., Florence, KY 41042-2978.

Nunan, D. (2003). Practical English Language Teaching ( $1^{\text {st }}$ Ed). Singapore: Mc. Graw Hill. Peacock, M. (1997). The effect of authentic materials on the motivation of EFL learners. ELT Journal, 51(2), 144-156.

Rahman, H., Thalib, S.B., \& Mahmud, A. Integrated Character Education in Social Sciences with Contextual Teaching and Learning Approach. The New Educational Review, 2(48), 53-64.

Rivers, W.M. (1981). Teaching foreign-language skills. University of Chicago Press, 5801 S. Ellis Ave., Chicago, IL 60637

Rogers, C.V., \& Medley, F.W., Jr. (1988). Language with a purpose: Using authentic materials in the foreign language classroom. Foreign Language Annals, 21, p. 467-478.

Saeedi, Z., \& Biri, A., (2016). The application of technology in teaching grammar to EFL learners: the role of animated sitcoms. Teaching English with Technology, 16 (2), 18-39.

Schmidt-Rinehart, B.C. (1994). The effects of topic familiarity on second language listening comprehension. The Modern Language Journal, 78, 179-189.

Shabunt, G., (2011). The Effectiveness of Instructional Vs. Authentic Video Materials for Developing Listening Comprehension Skills. Armenia: Unpublished thesis of American University of Armenia

Sherman, J., (2003). Using Authentic Video in the Language Classroom, Cambridge: Cambridge University Press.

Shian, C.S., \& Yunus, M.M. (2017). Audio clips in developing listening comprehension skills in Malaysian Primary ESL classrooms. Proceedings of the ICECRS, 1(1). 
Shrosbree, M. (2008). Digital video in the language classroom. The JALT CALL Journal, $4(1), 75-84$.

Stempleski, S. \& Tomalin, B. (1990). Videos in action recipes for using video in language teaching. New York: Prentice Hall.

Thomson, K., Leintz, P., Nevers, B., \& Witkowski, S. (2004). The interactive listening model: An approach of teaching and learning listening. The Journal of General Education, 53(4), 226-240.

Ur, P. (1996). A Course in Language Teaching: Practice and Theory. Cambridge: Cambridge University Press

Vijayavalsalan, B. (2016). Mind mapping as a strategy for enhancing essay writing skills. The New Educational Review, 3(44) 137-150.

Wagner, E. (2010). The effect of the use of video texts on ESL listening test-taker performance. Language Testing, 27(4), 493-513.

Wilberschied, L., \& Berman, P.M. (2004). Effect of using photos from authentic video as advance organizers on listening comprehension in an FLES Chinese class. Foreign Language Annals, 37(4), 534-540.

Woottipong, K. (2014). Effect of using video materials in the teaching of listening skills for university students. International Journal of Linguistics, 6 (4), 200.

Yang, J.C., Chen, C.H., \& Chang Jeng, M. (2010). Integrating video-capture virtual reality technology into a physically interactive learning environment for English learning. Computers \& Education, 55 (3), 1346-1356.

Yunus, M.M., Salehi, H., \& Amini, M. (2016). EFL Teachers' Cognition of Teaching English Pronunciation Techniques: A Mixed-Method Approach. English Language Teaching, 9(2), 20-42. 